1

3

4

\section{Viral Variants and Vaccinations: If We Can Change the COVID-19 Vaccine... Should We?}

\author{
$5 \quad{ }^{1}$ Department of Biological Sciences, Clemson University, Clemson, South Carolina, U.S.A \\ Sharon Bewick ${ }^{1}$
}

6

7

8 about vaccine formulation over the coming months.

Abstract

As we close in on one year since the COVID-19 pandemic began, hope has been placed on bringing the virus under control through mass administration of recently developed vaccines. Unfortunately, newly emerged, fast-spreading strains of COVID-19 threaten to undermine progress by interfering with vaccine efficacy. While a long-term solution to this challenge would be to develop vaccines that simultaneously target multiple different COVID-19 variants, this approach faces both developmental and regulatory hurdles. A simpler option would be to switch the target of the current vaccine to better match the newest viral variant. I use a stochastic simulation to determine when it is better to target a newly emerged viral variant and when it is better to target the dominant but potentially less transmissible strain. My simulation results suggest that it is almost always better to target the faster spreading strain, even when the initial prevalence of this variant is much lower. In scenarios where targeting the slower spreading variant is best, all vaccination strategies perform relatively well, meaning that the choice of vaccination strategy has a small effect on public health outcomes. In scenarios where targeting the faster spreading variant is best, use of vaccines against the faster spreading viral variant can save many lives. My results provide 'rule of thumb' guidance for those making critical decisions 
medRxiv preprint doi: https://doi.org/10.1101/2021.01.05.21249255; this version posted January 6, 2021. The copyright holder for this preprint (which was not certified by peer review) is the author/funder, who has granted medRxiv a license to display the preprint in perpetuity.

It is made available under a CC-BY-NC-ND 4.0 International license .

\section{Introduction}

On March 11, 2020, the World Health Organization (WHO) declared the COVID-19

27 outbreak a global pandemic ${ }^{1}$. Since then, much effort has focused on developing safe and

28 effective vaccines that can bring the world back to normality ${ }^{2}$. Remarkably, exactly 9 months

29 after the WHO declared a global pandemic, the U.S. Food and Drug Administration (FDA)

announced an Emergency Use Authorization (EUA) for the Pfizer-BioNTech COVID-19

31 vaccine $^{3}$ - the first vaccine against COVID-19 to receive approval in the United States.

32 Additional authorizations have followed rapidly. For instance, an EUA was issued for the

33 Moderna COVID-19 vaccine a mere one week after the EUA for the Pfizer-BioNTech vaccine ${ }^{4}$.

34 Notably, this timeline for vaccine development and approval is over four times faster than any

35 previous vaccine efforts ${ }^{5}$. Further, initial clinical trials suggest that these early vaccines against

36 COVID-19 are highly effective, with both Pfizer-BioNtech and Moderna reporting efficacies

37 exceeding $90 \%{ }^{6,7}$, which is comparable to some of the best vaccines currently in use.

38 In large part, the remarkable speed with which the world has developed safe, efficacious

39 COVID-19 vaccines is a result of years of advances in molecular biology. Indeed, both the

40 Pfizer-BioNTech vaccine and the Moderna vaccine rely on a novel messenger RNA (mRNA)

41 approach $^{8,9}$ for stimulating the immune system. Though there are some drawbacks of mRNA

42 vaccines - most notably the requirement for cold-chain storage - this technology greatly

43 facilitates rapid and targeted vaccine development based solely on the genetic sequence of the

44 virus $^{10}$. This, in turn, allows vaccine candidates to be made without ever needing to culture the

45 virus itself. Another related advantage of mRNA vaccines is their flexibility. In particular,

46 because their only requirement is the genetic code for a particular antigenic component of the

47 target virus, it is not difficult to alter these vaccines in response to strain variation. 
medRxiv preprint doi: https://doi.org/10.1101/2021.01.05.21249255; this version posted January 6, 2021. The copyright holder for this preprint (which was not certified by peer review) is the author/funder, who has granted medRxiv a license to display the preprint in perpetuity.

It is made available under a CC-BY-NC-ND 4.0 International license .

In early December 2020, the United Kingdom reported a novel and potentially

concerning COVID-19 variant, B.1.1. $7^{11,12}$. What is particularly troublesome about this variant is

that it has a large number of mutations -23 in total, 17 of which are non-silent ${ }^{12}$. Further, 8 of

51 these mutations occur in the spike protein, which is the portion of the virus responsible for

52 enabling viral entry into human cells ${ }^{12}$. These novel mutations include the N501Y mutation that

53 allows the virus to bind more tightly to the human angiotensin converting enzyme 2 (ACE2)

54 receptor ${ }^{13}$, as well as the $\mathrm{D} 614 \mathrm{G}$ deletion that appears to make the virus more transmissible

55 between individuals ${ }^{14}$. Substantial genetic changes, along with accelerating rates of spread, and a

56 rapid rise to dominance of the B.1.1.7 variant in Southern England ${ }^{15}$, suggest that the B.1.1.7 has

57 a fitness advantage. In fact, recent modeling studies indicate that the B.1.1.7 variant could be 50-

$5870 \%$ more transmissible than previous COVID-19 strains $^{11,16}$.

Beyond altered transmissibility, another threat of the B.1.1.7 mutant is that existing

60 vaccines may be less effective against it. This is because most vaccines in development

61 specifically target the viral spike protein $^{2}$. Currently Pfizer-BioNTech and Moderna are

62 conducting in vitro assays that will provide first estimates of the efficacy of existing vaccines

63 against the novel B.1.1.7 COVID-19 variant. Full assessment of vaccine efficacy will follow in a

64 matter of weeks to months, as existing vaccines are rolled-out in locations like Southern England

65 where the B.1.1.7 variant is dominant. However, even if current vaccines are efficacious against

66 B.1.1.7, the emergence of this viral variant is a warning call. In particular, we can expect

67 COVID-19 to continue to mutate and to generate novel variants that differ from the initial

68 vaccine targets. The obvious long-term solution is to develop vaccines that contain DNA from all

69 of the dominant COVID-19 variants in circulation (multivalent), much like the seasonal

70 influenza vaccine ${ }^{17}$. However, because mRNA vaccine technology is new, multivalent COVID- 
medRxiv preprint doi: https://doi.org/10.1101/2021.01.05.21249255; this version posted January 6, 2021. The copyright holder for this preprint (which was not certified by peer review) is the author/funder, who has granted medRxiv a license to display the preprint in perpetuity.

It is made available under a CC-BY-NC-ND 4.0 International license .

7119 mRNA vaccines have not been tested. Thus, it is unclear whether presenting multiple

72 antigenic components through mixed mRNAs will actually provide even immune coverage to all

73 components, or whether there will be interference effects ${ }^{18}$. Likewise, it is unclear whether there

74 are any additional health risks to mixed mRNA vaccines. As a consequence, multivalent

75 COVID-19 vaccines pose both development and regulatory hurdles. A simpler approach to

76 combat COVID-19 strain evolution is to 'switch out' the viral mRNA in the existing single strain

77 (monovalent) vaccine in response to changes in the dominance of the circulating strains.

78 Currently, for example, that could mean switching to the mRNA for the spike protein from the

79 B.1.1.7 viral variant.

While it may seem obvious that COVID-19 vaccines should be altered to track the

81 dominant viral strains in circulation, there are costs involved with switching. Further, without

82 sufficient cross-protection, vaccination against one viral variant will cause the other to rise to

83 dominance and vice versa, essentially leading to a game of whack-a-mole. While this scenario

84 cannot be avoided entirely, there may still be better and worse decisions in terms of the viral

85 variant that is selected for vaccine efforts. This is because not all viral variants are biologically

86 equivalent. Some viral variants, like B.1.1.7 are more transmissible. Others may be more

87 prevalent, or may have already swept a larger fraction of the population, at least at the time of the

88 initial vaccine roll-out. This, then, begs the question: When multiple COVID-19 viral variants

89 are circulating, and when vaccine cross-protection is not complete, which variant should be

90 targeted for vaccine scale-up during the initial vaccination phase?

91 In this paper, I use a simple stochastic simulation to examine the outcomes of various

92 vaccine strategies against two different co-circulating COVID-19 viral variants. In particular, I

93 examine how the best choice of vaccine target depends on the degree of cross-protection offered 
medRxiv preprint doi: https://doi.org/10.1101/2021.01.05.21249255; this version posted January 6, 2021. The copyright holder for this preprint (which was not certified by peer review) is the author/funder, who has granted medRxiv a license to display the preprint in perpetuity.

It is made available under a CC-BY-NC-ND 4.0 International license .

94 by vaccination and/or natural immunity to the alternate strain. I also consider how outcomes

95 depend on the relative transmissibilities of the different viral variants, their relative prevalence at

96 the beginning of the vaccination period, and existing natural immunity. Finally, I consider how

97 differences in the timing of vaccine roll-out can change predictions, and what this might mean as

98 we rapidly scale-up a series of different mRNA vaccines against the COVID-19 pandemic.

99

100 Method

101 I use the Gillespie algorithm $(\mathrm{GA})^{19}$ - a discrete-time, event-based simulation approach - to study

102 transmission of two different COVID-19 viral variants in a human population undergoing rapid

103 roll-out of a COVID-19 vaccine that is targeted at only one of the two variants (monovalent). For

104 each individual in the population, I assume that they can be in one of four potential infection

105 classes, one of four potential natural immunity classes and one of four potential vaccination

106 classes. Specifically, individuals can be: virus-free $(i=0)$, infected with the first viral variant $(i=$

107 1), infected with the second viral variant $(i=2)$ or infected with both viral variants $(i=3)$.

108 Likewise, individuals can be: fully naturally susceptible $(j=0)$, naturally immune to the first

109 viral variant $(j=1)$, naturally immune to the second viral variant $(j=2)$ or naturally immune to

110 both viral variants $(j=3)$. Finally, individuals can be: unvaccinated $(k=0)$, vaccinated against

111 the first viral variant $(k=1)$, vaccinated against the second viral variant $(k=2)$ or vaccinated

112 against both viral variants $(k=3)$. Ultimately, this leads to $4 \times 4 \times 4=64$ possible states for each

113 individual. I then define a matrix, $\boldsymbol{N}$, where each element, $N_{i, j, k}$, specifies the number of

114 individuals in the $i^{\text {th }}$ infection class, the $j^{\text {th }}$ natural immunity class and the $k^{\text {th }}$ vaccination class.

115 Depending on model assumptions, not all states may be possible, in which case $N_{i, j, k}=0$ (e.g., if

116 there are no double vaccinations, then $\left.N_{i, j, 3}=0\right)$. 


\section{Viral Transmission}

118 I assume frequency-dependent viral transmission. Thus, the probability of a new viral infection involving viral variant $i$ is proportional to both the number of individuals infected with that

120 variant and the number of individuals susceptible to that variant, and is inversely proportional to 121 total population size. I assume that natural immunity and/or vaccine-induced immunity impact the probability of transmission of each viral variant, but are not necessarily fully protective, even against the 'on-target' viral variant. Specifically

$$
\begin{aligned}
P_{T}\left(N_{i, j, k, t+\Delta t}=\right. & \left.n+1, N_{\gamma, j, k, t+\Delta t}=m-1 \mid N_{i, j, k, t}=n, N_{\gamma, j, k, t}=m\right) \\
& =\left\{\begin{array}{cc}
\frac{\beta_{i}\left(1-\max \left(\varepsilon_{j i}, v_{k i}\right)\right) N_{\gamma, j, k} \sum_{\hat{\jmath}, \hat{k}}\left(N_{i, \hat{\jmath}, \hat{k}}+N_{3, \hat{\jmath}, \hat{k}}\right) \Delta t}{\sum_{\hat{\imath}, \hat{\jmath}, \hat{k}} N_{\hat{\imath}, \hat{\jmath}, \hat{k}}} & i=1,2, \gamma=0 \\
\frac{\beta_{\gamma^{\prime}}\left(1-\max \left(\varepsilon_{j \gamma^{\prime}}, v_{k \gamma^{\prime}}\right)\right) N_{\gamma, j, k} \sum_{\hat{\jmath}, \hat{k}}\left(N_{\gamma^{\prime}, \hat{\jmath}, \hat{k}}+N_{3, \hat{\jmath}, \hat{k}}\right) \Delta t}{\sum_{\hat{\imath}, \hat{\jmath}, \hat{k}} N_{\hat{\imath}, \hat{\jmath}, \hat{k}}} & i=3, \gamma=1,2 \\
0 & \text { otherwise }
\end{array}\right.
\end{aligned}
$$

where $P_{T}\left(N_{i, j, k, t+\Delta t}=n+1, N_{\gamma, j, k, t+\Delta t}=m-1 \mid N_{i, j, k, t}=n, N_{\gamma, j, k, t}=m\right)$ is the probability of

an individual transferring from the $\gamma$ infection class to the $i$ infection class and $\gamma^{\prime}=\left\{\begin{array}{ll}1 & \gamma=2 \\ 2 & \gamma=1\end{array}\right.$.

$133 v_{k i}$ when $j=k$ (natural immunity and vaccine induced immunity confer similar levels of

134 protection). Further, I assume that $\varepsilon_{11}=\varepsilon_{22}=v_{11}=v_{22}$ and that $\varepsilon_{12}=\varepsilon_{21}=v_{12}=v_{21}$ (both

135 viral variants perform similarly in terms of the degree of conferred same-strain protection and the 
medRxiv preprint doi: https://doi.org/10.1101/2021.01.05.21249255; this version posted January 6, 2021. The copyright holder for this preprint (which was not certified by peer review) is the author/funder, who has granted medRxiv a license to display the preprint in perpetuity.

It is made available under a CC-BY-NC-ND 4.0 International license .

assumptions. First, a current infection with one viral variant does not impact the likelihood of a secondary infection with the alternate viral variant. Second, co-infected individuals spread each viral variant at the same rate as if they were singly infected. Third, immunity and vaccination

140 status do not impact the extent to which an infected individual spreads disease. Fourth, co-

141 infections are picked up serially, rather than as a result of direct transfer from a co-infected

142 individual. All of these assumptions could be relaxed, though with the requirement for 143 additional parameters.

145 Recovery

146 I assume a constant probability of recovery of infected individuals. Further, I assume that, upon

147 recovery, an individual acquires natural immunity to the viral variant that they were infected

148 with (or remains naturally immune, if they already had immunity to that particular strain). Thus,

$149 P_{R}\left(N_{0, \gamma, k, t+\Delta t}=n+1, N_{i, j, k, t+\Delta t}=m-1 \mid N_{0, \gamma, k, t}=n, N_{i, j, k, t}=m\right)=$$$
\left\{\begin{array}{cc}
r_{i, j, k} N_{i, j, k} \Delta t & i>0, j=0, i, \gamma=i \text { OR } i>0, j=1,2, i \neq j, \gamma=3 \\
0 & \text { otherwise }
\end{array}\right.
$$

where $P_{R}\left(N_{0, i, k, t+\Delta t}=n+1, N_{i, j, k, t+\Delta t}=m-1 \mid N_{0, i, k, t}=n, N_{i, j, k, t}=m\right)$ is the probability of whether an individual is infected with a single viral variant or is co-infected, and on the

156 immunity and vaccination status of the infected individual. However, in all models that I

157 consider, I assume $r_{i, j, k}=r$; thus all individuals have similar probabilities of recovery,

158 regardless of disease state or immunity status. 
medRxiv preprint doi: https://doi.org/10.1101/2021.01.05.21249255; this version posted January 6, 2021. The copyright holder for this preprint (which was not certified by peer review) is the author/funder, who has granted medRxiv a license to display the preprint in perpetuity.

It is made available under a CC-BY-NC-ND 4.0 International license .

Death

161 I assume a constant probability of death of infected individuals and do not consider additional

162 death or birth in the population. Specifically

163

$P_{D}\left(N_{i, j, k, t+\Delta t}=n-1 \mid N_{i, j, k, t}=n\right)=\left\{\begin{array}{cc}\mu_{i, j, k} N_{i, j, k} & i>0 \\ 0 & \text { otherwise }\end{array}\right.$

164 where $P_{D}\left(N_{i, j, k, t+\Delta t}=n-1 \mid N_{i, j, k, t}=n\right)$ is the probability of an individual from the $i$ infection

165 class being removed from the population. In equation (3), the probability of dying depends on

166 the particular viral infection, as well as the immunity status of the host. However, as with

167 recovery, for all models that I consider, I assume that $\mu_{i, j, k}=\mu_{i}$. This means that death rate is

168 only a function of the viral variant(s) causing the infection but does not depend on immune status

169 of the host.

170

171 Vaccination

172 I assume a constant probability of vaccination, and that vaccination does not take into account

173 the natural immunity status or infection status of the individual. I make this assumption given the

174 large number of asymptomatic infections that make it difficult to know whether a person has

175 been previously infected or, indeed, even whether a person is currently infected. I do, however,

176 assume that people who have already been vaccinated are not re-vaccinated. Finally, I assume

177 that vaccination proceeds at a fixed rate until all individuals willing to receive a vaccine have

178 done so. Once all willing individuals have been vaccinated, vaccination stops. Thus

$179 P_{V}\left(N_{i, j, \kappa, t+\Delta t}=n+1, N_{i, j, k, t+\Delta t}=m-1 \mid N_{i, j, \kappa, t}=n, N_{i, j, k, t}=m\right)=$

180

$\left\{\begin{array}{cc}\omega_{\kappa} & k=0, \kappa=1,2, \sum_{\hat{\imath}, \hat{\jmath}, \hat{k}=1,2} N_{\hat{\imath}, \hat{\jmath}, \hat{k}} / \sum_{\hat{\imath}, \hat{\jmath}, \hat{k}} N_{\hat{\imath}, \hat{\jmath}, \hat{k}}<\theta \\ 0 & \text { otherwise }\end{array}\right.$ 
medRxiv preprint doi: https://doi.org/10.1101/2021.01.05.21249255; this version posted January 6, 2021. The copyright holder for this preprint (which was not certified by peer review) is the author/funder, who has granted medRxiv a license to display the preprint in perpetuity.

It is made available under a CC-BY-NC-ND 4.0 International license .

where $P_{V}\left(N_{i, j, \kappa, t+\Delta t}=n+1, N_{i, j, k, t+\Delta t}=m-1 \mid N_{i, j, \kappa, t}=n, N_{i, j, k, t}=m\right)$ is the probability of

an individual with vaccination status $k$ receiving the vaccine and transitioning to vaccination status $\kappa, \omega_{\kappa}$ is the rate at which the vaccine is administered and $\theta$ is the fraction of the population willing to receive a vaccine.

\section{Parameters and Initial Conditions}

187 Except where noted otherwise, I assume the parameter values as outlined in Table 1. Briefly, I 188 assume that both vaccines and natural immunity are $95 \%$ effective at preventing infection when 189 targeted at the same viral variant. This is commensurate with early reports from both Pfizer-

190 BioNTech and Moderna ${ }^{6,7}$, as well as low reports of re-infection across the world. Likewise, I

191 assume that a person who has been infected can spread the virus for 10 days ${ }^{20}$ (notice that it does

192 not matter whether the person has symptoms for any or all of this period). I assume that the death 193 rate due to disease is 0.0006 /day which, for a 10 day infection period, leads to a $0.6 \%$ death rate, 194 again commensurate with current reports on COVID-19 infection fatality ratios (IFRs) ${ }^{21}$. Finally, 195 I assume that a person infected with the original COVID-19 variant spreads the disease to, on 196 average, 2 additional people ${ }^{22}$, while a person infected with the new viral variant spreads the 197 disease to, on average, 3 additional people (i.e., 50\% more infectious). Finally, I assume that $198100 \%$ of the population is willing to/forced to receive the vaccine, and that 5000 people per day, 199 can be vaccinated in a 500,000 person population (i.e., it takes 100 days or approximately 3 200 months to vaccinate the entire focal population).

201 For initial conditions, I assume that, at the start of the simulation, a pre-defined fraction 202 of the population, $\rho_{1}$, is infected with the first viral variant, and a pre-defined fraction of the 203 population, $\rho_{2}$, is infected with the second viral variant. I ignore co-infections at the beginning of 
medRxiv preprint doi: https://doi.org/10.1101/2021.01.05.21249255; this version posted January 6, 2021. The copyright holder for this preprint (which was not certified by peer review) is the author/funder, who has granted medRxiv a license to display the preprint in perpetuity.

It is made available under a CC-BY-NC-ND 4.0 International license .

204 the simulation under the assumption that $\rho_{1} \rho_{2} \sum_{\hat{\imath}, \hat{\jmath}, \hat{k}} N_{\hat{\imath}, \hat{\jmath}, \hat{k}} \ll 1$ for reasonably small $\rho_{1}$ and/or $\rho_{2}$.

205 Likewise, I assume that, at the start of the simulation, a pre-defined fraction of the population,

$206 \varphi_{1}$, is immune as a result of previous infection with the first viral variant, and that a pre-defined

207 fraction of the population, $\varphi_{2}$, is immune as a result of previous infection with the second viral

208 variant. As with infection, I assume that there are no individuals who have acquired natural

209 immunity to both viruses, which is a good approximation when either $\varphi_{1}$ or $\varphi_{2}$ are small (at least

210 one strain has not been circulating for a long time) or when $\varepsilon_{12}$ or $\varepsilon_{21}$ are large (natural cross-

211 protection is high, making serial infection with different strains less likely). In practice, most

212 simulations that I consider assume that the second COVID-19 strain is a recent introduction, and

213 thus $\varphi_{2} \sim 0$.

214 Table 1: Parameters and initial conditions used in simulations

\begin{tabular}{|l|c|c|}
\hline \multicolumn{1}{|c|}{ Parameter } & Symbol & Value \\
\hline Natural immunity against same variant & $\varepsilon_{11}, \varepsilon_{22}$ & $0.95^{6,7}$ \\
\hline Natural cross-protection against the opposite variant & $\varepsilon_{12}, \varepsilon_{21}$ & 0.70 \\
\hline Vaccine induced immunity against same variant & $v_{11}, v_{22}$ & 0.95 \\
\hline Vaccine induced cross-protection against the opposite variant & $v_{12}, v_{21}$ & 0.70 \\
\hline Recovery rate & $r$ & $0.1^{20}$ \\
\hline Death rate & $\mu_{1}, \mu_{2}$ & $0.0006^{21}$ \\
\hline Transmission rate of COVID-19 variant 1 & $\beta_{1}$ & $0.2^{22}$ \\
\hline Transmission rate of COVD-19 variant 2 & $\beta_{2}$ & 0.3 \\
\hline Fraction of population willing to receive vaccine & $\theta$ & 1 \\
\hline Vaccination rate & $\omega_{1}+\omega_{2}$ & 5000 \\
\hline Population size & $N_{\hat{\imath} \hat{\jmath}, \hat{k}} N_{\hat{\imath}, \hat{\jmath}, \hat{k}}$ & 500000 \\
\hline Initial fraction infected with variant 1 & $\rho_{1}$ & 0.001 \\
\hline Initial fraction infected with variant 2 & $\rho_{2}$ & 0.00001 \\
\hline Initial fraction naturally immune to variant 1 & $\varphi_{1}$ & 0.10 \\
\hline Initial fraction naturally immune to variant 2 & $\varphi_{2}$ & 0 \\
\hline
\end{tabular}

216 Python code for model simulations is provided at:

217 https:/github.com/bewicklab/COVID-Vaccination-Strategies 
medRxiv preprint doi: https://doi.org/10.1101/2021.01.05.21249255; this version posted January 6, 2021. The copyright holder for this preprint (which was not certified by peer review) is the author/funder, who has granted medRxiv a license to display the preprint in perpetuity.

It is made available under a CC-BY-NC-ND 4.0 International license .

\section{Results}

219 In the analysis that follows, I consider three different vaccination strategies. First, I consider a

220 scenario where all doses of the vaccine are targeted against viral variant 1 (blue lines). Second, I

221 consider a scenario where all doses of the vaccine are targeted against viral variant 2 (red lines).

222 Finally, I consider a scenario where two different types of vaccines are in use, with $50 \%$ of the

223 doses targeted against viral variant 1 , and $50 \%$ of the doses targeted against viral variant 2

224 (purple lines; this could be achieved, for example, if Pfizer-BioNTech and Moderna produced

225 different vaccines, each targeting the opposite viral variant). For each scenario, I consider three

226 metrics: (1) total deaths from the start of the simulation until the virus goes extinct, (2) peak

227 number of infections at any given time and (3) number of days until the virus goes extinct. Total

228 deaths provides an estimate of the costs of the different strategies in terms of human life. Total

229 deaths are also proportional to total infections, thus giving a sense of the overall scale of the viral

230 outbreak for each scenario. Peak number of infections is important, because an outbreak that has

231 a higher number of infectious individuals at any single point in time is more likely to overwhelm

232 healthcare facilities. Thus, even if the total sizes of two different outbreaks are the same, death

233 rates are likely to be lower for the outbreak with a lower peak infection rate (which typically

234 implies an outbreak that is spread over a longer period of time - note that my model assumes a

235 constant death rate, thus total deaths does not account for variation in death rate due to

236 overwhelmed medical facilities). Finally, the number of days until the virus goes extinct gives a

237 sense of the time required to reach herd immunity through a combination of natural infection and

238 vaccination. Longer times to viral extinction do not necessarily mean worse outbreaks in terms

239 of total infections and deaths, although they do imply a longer period over which masks and 
medRxiv preprint doi: https://doi.org/10.1101/2021.01.05.21249255; this version posted January 6, 2021. The copyright holder for this preprint (which was not certified by peer review) is the author/funder, who has granted medRxiv a license to display the preprint in perpetuity.

It is made available under a CC-BY-NC-ND 4.0 International license .

A.

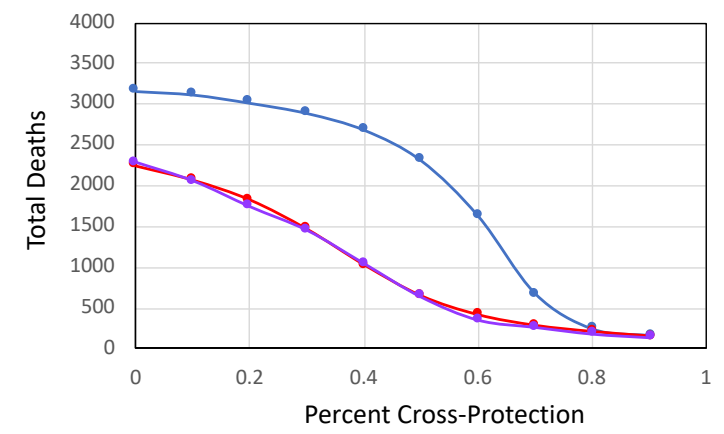

C.

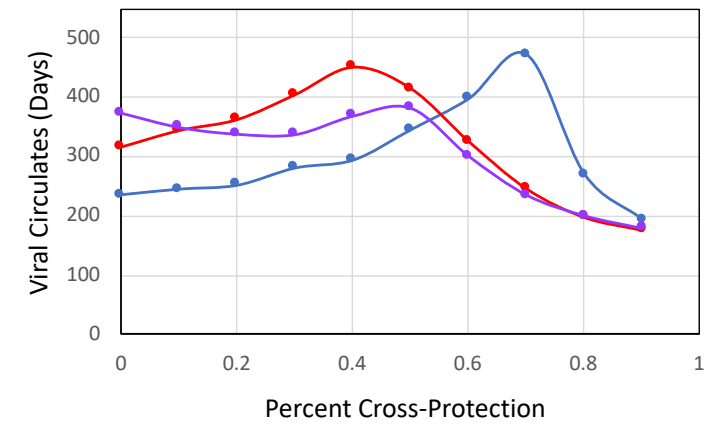

B.

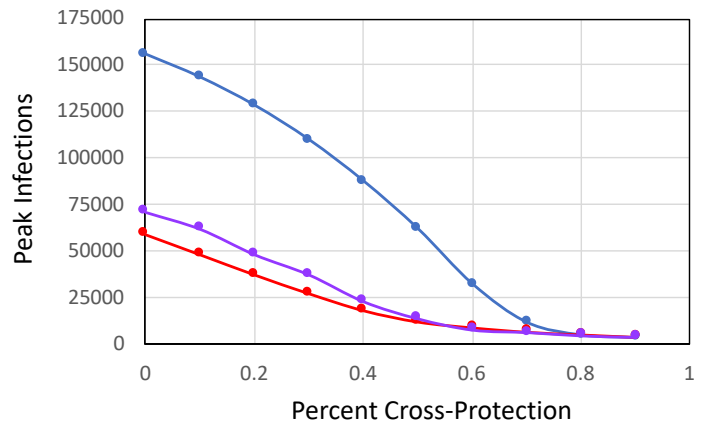

$\longrightarrow$ vaccinate for variant 1 (slow)

$\longrightarrow$ vaccinate for variant 2 (fast)

$\longrightarrow$ vaccinate 50:50 variant 1 and variant 2

244 Fig. 1 (A) Total number of deaths, (B) peak infections and (C) time to virus extinction as a function of the degree of natural and vaccine-induced cross-protection $\left(v_{12}=v_{21}=\varepsilon_{12}=\varepsilon_{21}\right)$ assuming a vaccination strategy targeting viral variant 1 (blue, slower spreading), a vaccination strategy targeting viral variant 2 (red, faster spreading) and a mixed strategy with $50 \%$ of the population receiving the vaccine against viral variant 1 and $50 \%$ receiving the vaccine against viral variant 2 . All parameters and initial conditions except those associated with crossprotection $\left(v_{12}, v_{21}, \varepsilon_{12}, \varepsilon_{21}\right)$ are as defined in Table 1 . Results shown are median values over 30 simulation trials.

254 Figure 1 shows the total number of deaths (A), peak infections (B) and time to virus extinction 
medRxiv preprint doi: https://doi.org/10.1101/2021.01.05.21249255; this version posted January 6, 2021. The copyright holder for this preprint (which was not certified by peer review) is the author/funder, who has granted medRxiv a license to display the preprint in perpetuity.

It is made available under a CC-BY-NC-ND 4.0 International license .

258 with one of the two virus strains, then approximately 3000 individuals will die. Likewise, if the

259 entire population is infected with both of virus strains (simultaneously or sequentially), then

260 approximately 6000 individuals will die. Because herd immunity is typically achieved at

261 infection rates less than 100\%, 3000 and 6000 deaths represent upper bounds for single

262 infections and double infections respectively. Nevertheless, these bounds help to frame

263 simulation results.

As expected, when cross-protection is close to zero, vaccination against one of the two

265 viral strains cuts the total death rate in half. However, it does nothing to prevent deaths from the

266 off-target viral variant. Because of this, vaccination against the more transmissible virus (in this

267 case, viral variant 2) is almost always optimal, even if the less transmissible virus is initially

268 present at substantially higher rates. This is because, regardless of initial conditions, the off-

269 target variant will inevitably sweep the population. The virus that is more transmissible,

270 however, will infect a higher proportion of the population prior to reaching herd immunity.

271 Consequently, vaccinating against this more transmissible strain is the better option when there is

272 little to no cross-protection.

273 Although faster spread of viral variant 2 is the primary factor favoring use of this strain as

274 the vaccine target at low levels of cross-protection, there are two additional advantages to

275 focusing on viral variant 2 . Both are related to the fact that viral variant 1 is more prevalent.

276 While somewhat counterintuitive, higher prevalence of a particular strain prior to vaccination

277 can actually make it less effective to target that strain with the vaccine (see Fig. 5). This is

278 because higher viral prevalence goes hand-in-hand with higher levels of natural immunity, which

279 has two consequences. First, if one of the two viral variants will inevitably sweep the population

280 (i.e., low cross-protection), then it is preferable that this be the variant with more existing natural 
medRxiv preprint doi: https://doi.org/10.1101/2021.01.05.21249255; this version posted January 6, 2021. The copyright holder for this preprint (which was not certified by peer review) is the author/funder, who has granted medRxiv a license to display the preprint in perpetuity.

It is made available under a CC-BY-NC-ND 4.0 International license .

281 immunity, since fewer additional deaths will be necessary to reach herd immunity. Second, when

282 the vaccine is targeted against the more prevalent variant, more vaccine doses are wasted

283 protecting individuals who are already naturally immune (see Figure 5). By contrast, wasted

284 vaccine doses less common when the vaccine protects against a strain without much pre-existing

285 natural immunity. Again, this disfavors use of the more prevalent strain as the vaccine target (in

286 this case, variant 1).

Interestingly, a relatively high level of cross-protection is required before vaccination

288 with the more prevalent but slower spreading variant becomes a competitive strategy. Increasing

289 cross-protection from $0 \%$ to $50 \%$, for instance, only reduces total deaths by $<30 \%$ when the

290 vaccine is targeted against the prevalent but slow spreading variant 1 . By contrast, cross-

291 protection has a much stronger effect earlier on when the vaccine is targeted against the fast

292 spreading variant 2 . In this case increasing cross-protection from $0 \%$ to $50 \%$ causes a $>70 \%$

293 reduction in deaths. Notably, even at 90\% cross-protection, vaccination against the slow

294 spreading variant still underperforms in terms of preventing deaths.

295 Surprisingly, a mixed strategy, where half of the population receives the vaccine against

296 the slow spreading variant, while the other half receives the vaccine against the fast spreading

297 variant, performs almost as well as fully targeting the fast-spreading variant. This is particularly

298 notable, since a mixed strategy may be more realistic to implement, at least in the near-term, for

299 COVID-19. A mixed strategy, for example, would only require one or a few vaccine-makers to

300 alter the formulations of their vaccines. Notice, however, that my simulations assume

301 randomization of the two vaccines throughout the entire vaccine roll-out period - thus results

302 could be different if the two different vaccines were rolled out on different timelines or in

303 different spatial locations. 
medRxiv preprint doi: https://doi.org/10.1101/2021.01.05.21249255; this version posted January 6, 2021. The copyright holder for this preprint (which was not certified by peer review) is the author/funder, who has granted medRxiv a license to display the preprint in perpetuity.

It is made available under a CC-BY-NC-ND 4.0 International license .

Like deaths, peak infections are also much higher under the scenario with vaccination against the prevalent but slow spreading variant 1 . Interestingly, however, peak infections are also higher for the mixed vaccination strategy as compared to vaccination against viral variant 2 ,

307 at least when cross-protection $<50 \%$. This contrasts what was seen for total deaths. Nevertheless,

308 the mixed strategy still performs substantially better than vaccination against the slow spreading

309 variant 1 over most of the range of potential cross-protection levels. At high cross- protection,

$310(80-90 \%)$, differences in the different vaccination strategies are minimal, and the mixed strategy,

311 or even vaccination against the slow spreading viral variant can actually yield lower peak

312 infection levels.

Times to viral extinction tend to be unimodal, at least for strategies that target a single

314 viral variant. This is because, at low cross-protection, the off-target variant rapidly sweeps the

315 population, driving its own demise over a short period of time (at least in the absence of

316 introduction of newly susceptible individuals through birth or waning immunity). Meanwhile the

317 vaccine rapidly suppresses the on-target variant. Conversely, at high levels of cross-protection,

318 the vaccine itself leads to rapid extinction of both variants. At intermediate levels of cross-

319 protection, however, spread of the off-target viral variant is slowed, but not stopped, leading to

320 longer persistence of this strain in the population. While viral persistence peaks around $40 \%$

321 cross protection for the mixed strategy and the strategy that targets the fast-spreading variant 2 , it

322 peaks at a much higher $70 \%$ cross protection for the strategy that targets the slow-spreading

323 variant 1. Alarmingly, when the vaccine targets viral variant 1 , the virus can persist nearly 1.5

324 years after vaccination begins, even with a rapid vaccine roll-out of 3 months. 
medRxiv preprint doi: https://doi.org/10.1101/2021.01.05.21249255; this version posted January 6, 2021. The copyright holder for this preprint (which was not certified by peer review) is the author/funder, who has granted medRxiv a license to display the preprint in perpetuity.

It is made available under a CC-BY-NC-ND 4.0 International license .

328 Figure 2 shows the total number of deaths (A), peak infections (B) and time to virus extinction

(C) as a function of the transmission rate of the faster spreading viral variant 2 . In these simulations, I assume that viral variant 1 spreads at a rate of 0.2 person $^{-1}$ day $^{-1}$. For a typical

A.

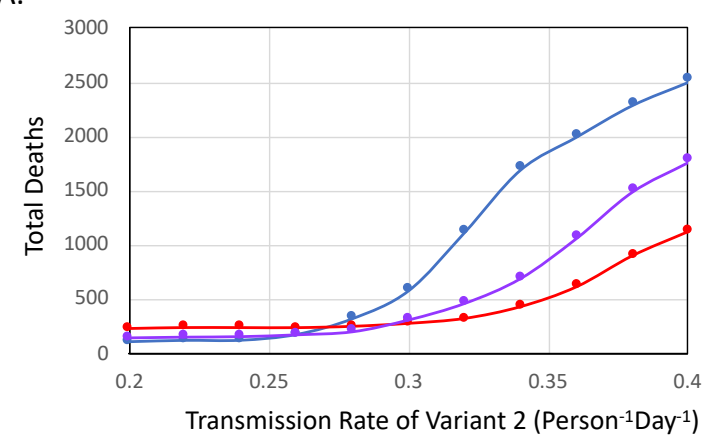

C.

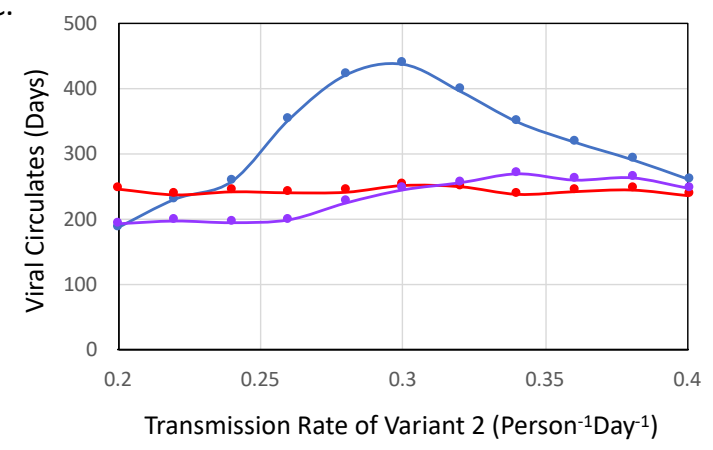

B.

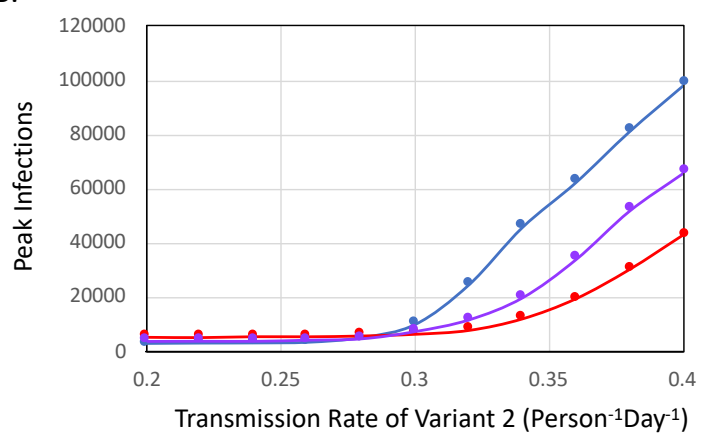

$\longrightarrow$ vaccinate for variant 1 (slow)

$\longrightarrow$ vaccinate for variant 2 (fast)

$\longrightarrow$ vaccinate 50:50 variant 1 and variant 2

Fig. 2 (A) Total number of deaths, (B) peak infections and (C) time to virus extinction as a function of the transmission rate of viral variant $2\left(\beta_{2}\right.$, faster spreading) assuming a vaccination strategy targeting viral variant 1 (blue, slower spreading), a vaccination strategy targeting viral variant 2 (red, faster spreading) and a mixed strategy with $50 \%$ of the population receiving the vaccine against viral variant 1 and the other 50\% receiving the vaccine against viral variant 2 . All parameters and initial conditions except the transmission rate of the second viral variant $\left(\beta_{2}\right)$ are as defined in Table 1. Results shown are median values over 30 trials.

340 infectious period of 10 days, this means that each person, on average, spreads the virus to two

341 additional people in a fully susceptible population. This estimate is commensurate with current measures of $R_{0}$ for COVID-1922. By extension, for the range of transmissibilities considered in

343 Figure 2, each person infected with viral variant 2 transmits the virus to between 2 and 4 
medRxiv preprint doi: https://doi.org/10.1101/2021.01.05.21249255; this version posted January 6, 2021. The copyright holder for this preprint (which was not certified by peer review) is the author/funder, who has granted medRxiv a license to display the preprint in perpetuity.

It is made available under a CC-BY-NC-ND 4.0 International license .

344 additional individuals in a fully susceptible population. This is in keeping with the estimate that

345 the new B.1.1.7 COVID-19 strain is 50-70\% more transmissible than its predecessor ${ }^{11,16}$. Not

346 surprisingly, increasing transmissibility of the second viral variant increases overall deaths, as

347 well as peak infections at the height of the outbreak. However, the rate of increase depends on

348 vaccination strategy. When there is not much difference between the transmission rates of the

349 two viral variants, it is actually best to vaccinate against the more prevalent but slower spreading

350 viral variant 1 . This is because the second viral variant is 100 -fold less common at the beginning

351 of the simulation. Thus, with sufficient cross-protection $\left(\varepsilon_{12}=\varepsilon_{21}=0.7\right.$ in Figure 2$)$, and a

352 reasonably fast vaccine roll-out (100 days), it is best to target the more prevalent strain.

353 However, the initial advantage gained by being more prevalent dissipates rapidly as the

354 transmission rate of the second viral variant increases. Thus, when the second variant spreads

$35550 \%$ faster than the first, vaccination against the second strain is marginally better (see also

356 Figure 1) and when the second variant spreads twice as fast as the first, vaccinating against the

357 faster spreading second strain dramatically reduces total deaths, as well as peak infection rates.

358 For most of the range in Figure 2, the mixed vaccination strategy is intermediate to either

359 single vaccination strategy in terms of total deaths and peak infections. However, while the

360 difference between the mixed strategy and vaccination against viral variant 2 is minimal at $\beta_{2}=$

3610.3 (see also Figure 1), this difference increases rapidly for $\beta_{2}>0.3$, such that, when the second

362 viral variant spreads twice as fast as the first, $\beta_{2}=0.4$, vaccinating against the second variant

363 save many lives, even compared to the mixed strategy. Thus, the benefits of the mixed strategy

364 seen in Figure 1 do not necessarily hold when the second viral variant is significantly more

365 transmissible. Notably, the benefit of developing vaccines against the faster spreading virus 
medRxiv preprint doi: https://doi.org/10.1101/2021.01.05.21249255; this version posted January 6, 2021. The copyright holder for this preprint (which was not certified by peer review) is the author/funder, who has granted medRxiv a license to display the preprint in perpetuity.

It is made available under a CC-BY-NC-ND 4.0 International license .

emerge despite the relatively high cross-protection levels $\left(\varepsilon_{12}=\varepsilon_{21}=0.7\right)$ assumed in Figure 2 and despite the 100-fold greater prevalence of the first variant at the beginning of the simulation.

Viral times to extinction are largely independent of the transmission rate of the second variant when the vaccine is targeted against this variant. This makes sense. When vaccination is against the second viral variant, the final stages of the outbreak are largely determined by spread

371 of the first viral variant, meaning that the final stages of the outbreak are largely independent of

372 the properties of the second viral strain. When the vaccine in use is against the first viral variant,

373 however, the time to viral extinction is unimodal. This can be understood as follows: when the

374 second viral variant spreads slowly, it can be rapidly brought under control by cross-protection

375 from infection/vaccination against the first variant. However, rapid control through vaccination

376 is less likely when the second variant spreads more rapidly. In this case, the second variant has

377 greater potential to infect a larger fraction of the population before cross-protection, combined

378 with natural immunity, finally bring the second variant under control. For faster and faster spread

379 of the second variant, however, natural immunity occurs earlier and earlier, leading to a decrease

380 in viral time to extinction.

\section{Vaccine Roll-out}

383 Figure 3 shows the total number of deaths (A), peak infections (B) and time to virus extinction

384 (C) as a function of the number of people vaccinated for the virus each day. For all of the

385 simulations in Figure 3, I assume a population size of 500,000 individuals, thus it would take 100 386 days to vaccinate the entire population at a rate of 5000 people/day, and 50 days to vaccinate the 387 entire population at a rate of 10000 people/day. As expected, total deaths and peak infection rates 388 decrease sharply with increased rate of vaccination roll-out for all vaccination strategies. 
medRxiv preprint doi: https://doi.org/10.1101/2021.01.05.21249255; this version posted January 6, 2021. The copyright holder for this preprint (which was not certified by peer review) is the author/funder, who has granted medRxiv a license to display the preprint in perpetuity.

It is made available under a CC-BY-NC-ND 4.0 International license .

A.

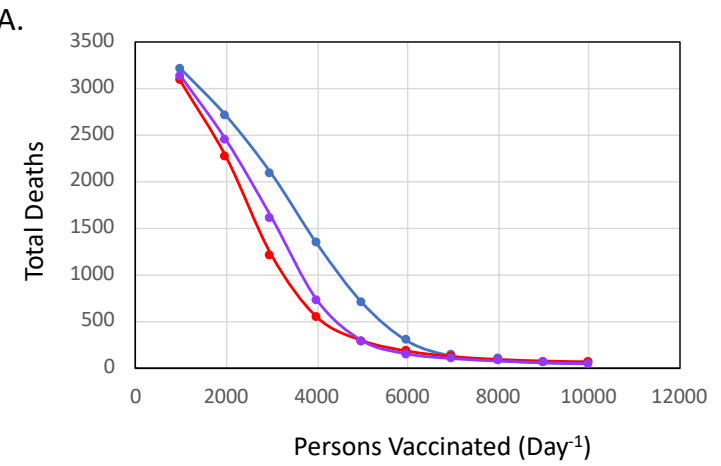

C.

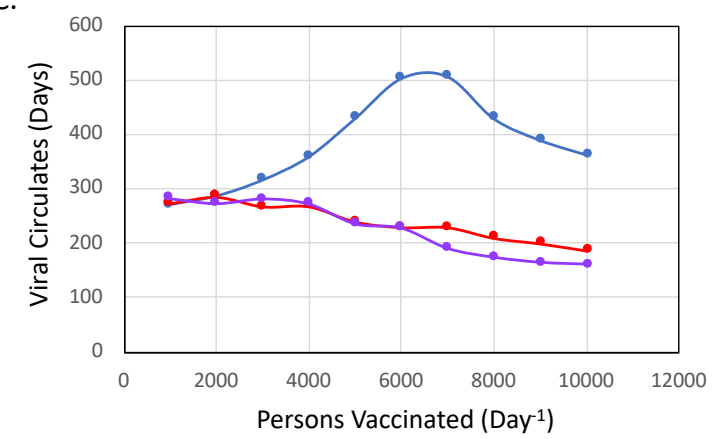

B.

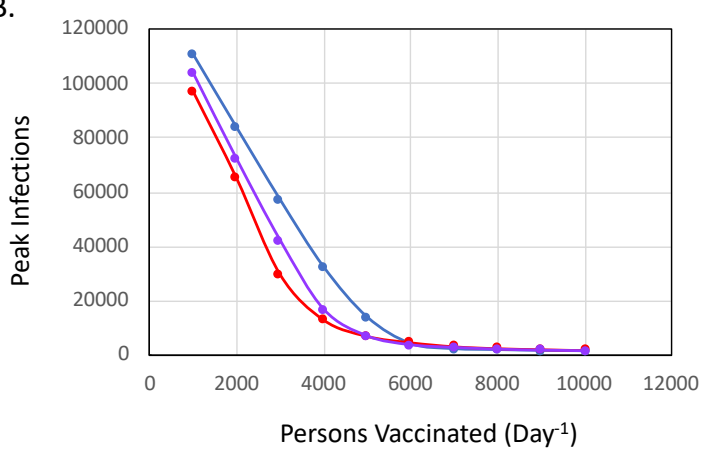

$\longrightarrow$ vaccinate for variant 1 (slow)

$\longrightarrow$ vaccinate for variant 2 (fast)

vaccinate 50:50 variant 1 and variant 2

390 Fig. 3 (A) Total number of deaths, (B) peak infections and (C) time to virus extinction as a function of vaccine roll-out rate, $\omega_{1}+\omega_{2}$, assuming a vaccination strategy targeting viral variant 1 (blue, slower spreading), a vaccination strategy targeting viral variant 2 (red, faster spreading) and a mixed strategy with $50 \%$ of the population receiving the vaccine against viral variant 1 and the other 50\% receiving the vaccine against viral variant 2 . All parameters and initial conditions except overall vaccination rate $\left(\omega_{1}+\omega_{2}\right)$ are as defined in Table 1. Results shown are median values over 30 trials.

However, over the range from 1000-5000 people/day (i.e., 500-100 days to vaccinate the

population), the decrease in deaths and peak infections as a function of vaccine rollout rate is

403 because slower vaccine roll-outs leave added time for the faster spreading variant to take over,

404 even from a significant early deficit. When the vaccine roll-out is rapid (less than two months), 
medRxiv preprint doi: https://doi.org/10.1101/2021.01.05.21249255; this version posted January 6, 2021. The copyright holder for this preprint (which was not certified by peer review) is the author/funder, who has granted medRxiv a license to display the preprint in perpetuity.

It is made available under a CC-BY-NC-ND 4.0 International license .

vaccination strategies in terms of total deaths, and outperforms vaccination against variant 2 in

407 terms of peak infections when the entire population can be vaccinated within 100 days. Further,

408 when full vaccination can be completed within $\sim 60$ days ( 2 months), vaccination against the first

409 viral variant actually leads to the lowest peak infection rates, though it still gives higher total

410 deaths than the mixed vaccination strategy.

411 For both vaccination against the fast-spreading virus and the mixed vaccination strategy,

412 time to viral extinction decreases with increasing vaccine roll-out rates, commensurate with the

413 expectation that faster vaccination of the population leads to faster suppression of the virus.

414 Vaccination against the first viral variant, by contrast, leads to a peak in viral extinction times as

415 a function of vaccine roll-out rate. Again, this is a result of the trade-off between rapid

416 development of herd immunity at low roll-out rates, rapid development of vaccine-induced

417 immunity at fast roll-out rates, and a peak in the middle, where vaccination slows viral spread

418 down, but does not immediately suppress it.

\section{$420 \quad$ Initial Infection Rates}

421 Figure 4 shows the total number of deaths (A), peak infections (B) and time to virus extinction

422 (C) as a function of the number of people initially infected with viral variant 2 . For these

423 simulations, I keep the total number of initial infections constant, thus when there are more

424 individuals infected with viral variant 2 , there are fewer infected with viral variant 1 . In order to

425 span a wide range of variant 1: variant 2 infection ratios while maintaining at least 5 individuals

426 infected with variant 2 (below 5 individuals, there is a sizeable likelihood of stochastic extinction

427 of the second variant), I assume a much higher baseline infection rate in Figure 4 as compared to 
medRxiv preprint doi: https://doi.org/10.1101/2021.01.05.21249255; this version posted January 6, 2021. The copyright holder for this preprint (which was not certified by peer review) is the author/funder, who has granted medRxiv a license to display the preprint in perpetuity.

It is made available under a CC-BY-NC-ND 4.0 International license .

A.

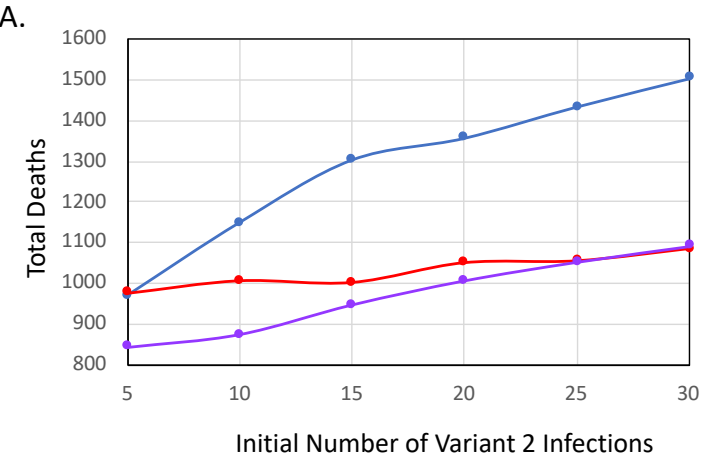

C.

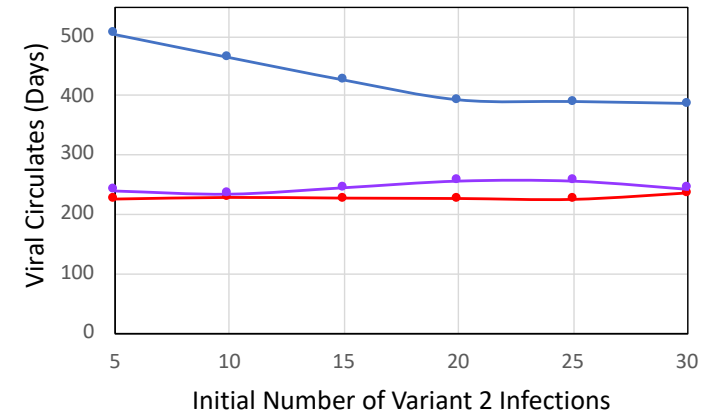

B.

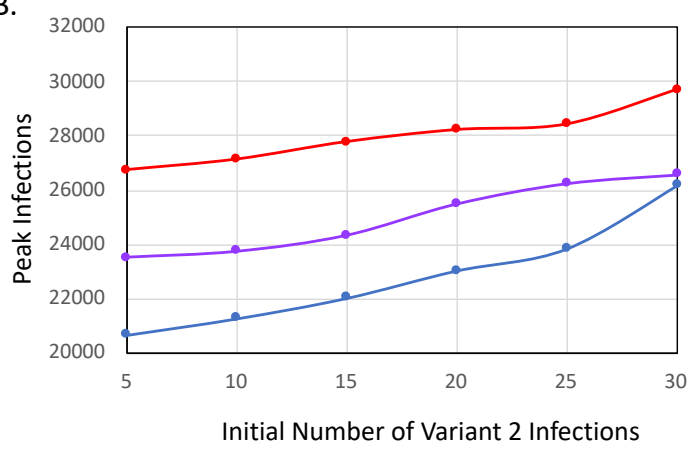

$\longrightarrow$ vaccinate for variant 1 (slow)

$\longrightarrow$ vaccinate for variant 2 (fast)

$\longrightarrow$ vaccinate 50:50 variant 1 and variant 2

430 Fig. 4 (A) Total number of deaths, (B) peak infections and (C) time to virus extinction as a function of the initial number of people in the population infected with viral variant 2 , $\rho_{2} \sum_{i, j, k} N$, and assuming a vaccination strategy targeting viral variant 1 (blue, slower spreading), a vaccination strategy targeting viral variant 2 (red, faster spreading) and a mixed strategy with $50 \%$ of the population receiving the vaccine against viral variant 1 and the other $50 \%$ receiving the vaccine against viral variant 2 . All parameters and initial conditions except initial fractions of infected individuals are as shown in Table 1. For initial fractions of infected individuals, I assume a constant total fraction, such that $\left(\rho_{1}+\rho_{2}\right) \sum_{i, j, k} N=5005$. Notice that this is a 10fold higher initial infection rate than what is used in Figures 1-3. Results shown are median values over 30 trials.

442 the outset of the simulation, as compared to the $0.1 \%$ infection rate that I use in Figures 1-3.

444 variant is still generally less effective at preventing deaths. At best, vaccinating against the slow

445 spreading viral variant 1 performs about as well as vaccinating against the fast spreading viral variant 2 , and even this requires that the initial number of variant 2 infections be very low $(\leq 5$

447 total variant 2 infections and a 1000:1 ratio of variant 1 to variant 2 infections in a population of 
medRxiv preprint doi: https://doi.org/10.1101/2021.01.05.21249255; this version posted January 6, 2021. The copyright holder for this preprint (which was not certified by peer review) is the author/funder, who has granted medRxiv a license to display the preprint in perpetuity.

It is made available under a CC-BY-NC-ND 4.0 International license .

448 500,000). More commonly, however, vaccinating against the slow spreading variant 1 leads to

449 many more deaths than vaccinating against the fast spreading variant 2 . While vaccinating

450 against the slow-spreading strain is a poor strategy, the mixed vaccination strategy actually

451 outperforms both single variant strategies over a wide range of infection ratios. Indeed, up to a

452 variant 1:variant 2 infection ratio of approximately 200, the mixed strategy prevents the most

453 deaths. Interestingly, although poor in terms of preventing deaths, vaccination against variant 1

454 can actually lower peak infection rates (but see Figures 1-3), suggesting that it is not necessarily

455 a poor strategy along all public health dimensions. Initial infection ratios do not have strong

456 impacts on time to virus extinction for any of the vaccine strategies considered.

457

458 Existing Natural Immunity

459 Because COVID-19 has been spreading in most locations since February-March 2020, many

460 people have acquired natural immunity, and this could potentially alter the benefits of the

461 different vaccination strategies. I explore this effect in Figure 5. In Figures 5A,B, I assume that

462 all existing natural immunity is towards the first viral variant, with the second viral variant being

463 a very recent introduction. As expected, increasing overall rates of immunity to viral variant 1 at

464 the start of the simulation decreases both total deaths and peak infection rates. Because, however,

465 the rate of decrease is similar across all vaccination strategies, the overall level of natural

466 immunity to the first viral variant has minimal impact on the choice of vaccination strategy. In

467 Figures 5C,D, I consider a scenario where $10 \%$ of the population has natural immunity, but for

468 some fraction of individuals this immunity is targeted against viral variant 1 , and for others it is

469 targeted against viral variant 2. Unlike changes in the overall levels of immunity, changes in the 
medRxiv preprint doi: https://doi.org/10.1101/2021.01.05.21249255; this version posted January 6, 2021. The copyright holder for this preprint (which was not certified by peer review) is the author/funder, who has granted medRxiv a license to display the preprint in perpetuity.

It is made available under a CC-BY-NC-ND 4.0 International license .

A.

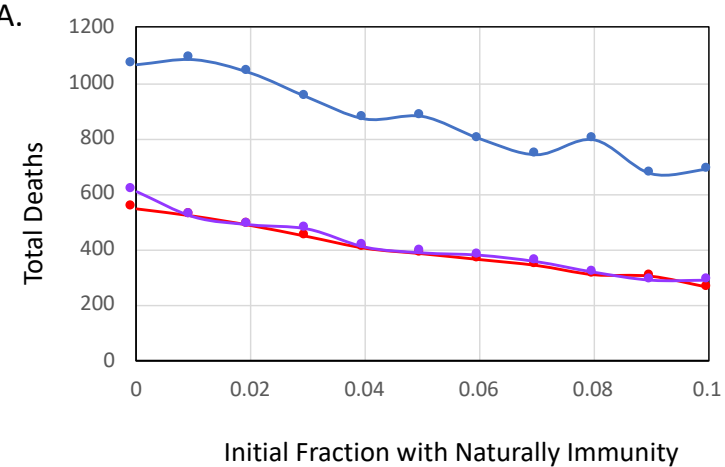

C.

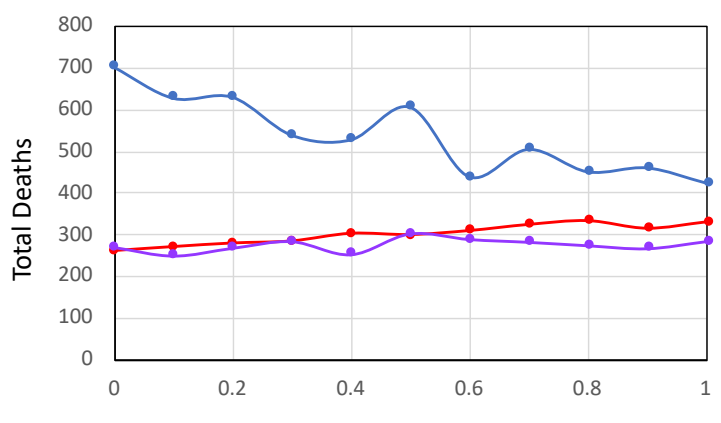

Fraction with Natural Immunity to Variant 2

$\longrightarrow$ vaccinate for variant 1 (slow)

$\longrightarrow$ vaccinate for variant 2 (fast)

$\longrightarrow$ vaccinate 50:50 variant 1 and variant 2
B.

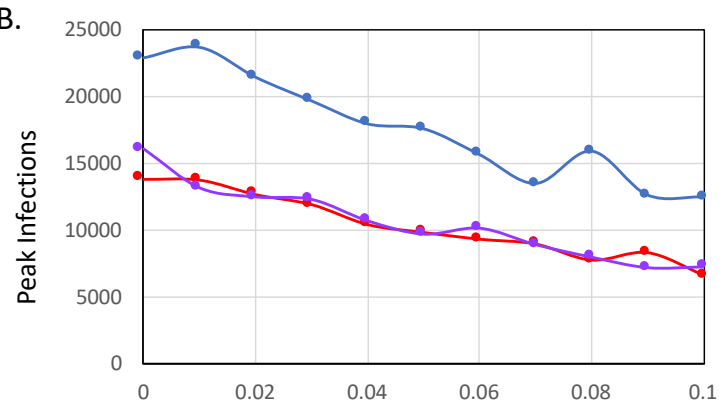

Initial Fraction with Naturally Immunity

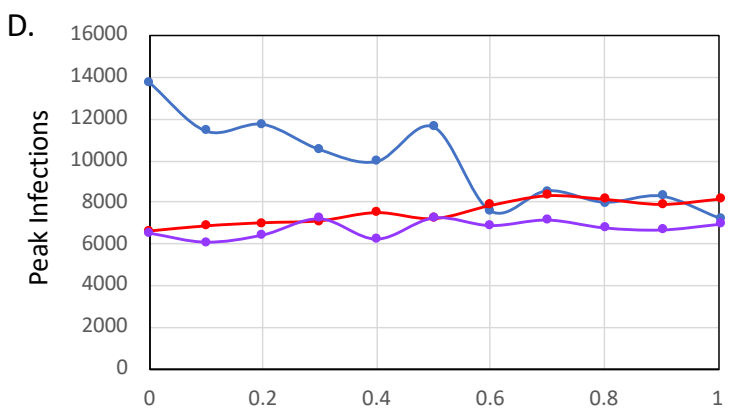

Fraction with Natural Immunity to Variant 2

471 Fig. 4 (A,C) Total number of deaths and (B,D) peak infections as a function of (A,B) the initial fraction of the population with natural immunity to viral variant 1 and assuming no immunity to viral variant 2 or (C,D) and the fraction of naturally immune individuals protected against viral variant 2, assuming an overall level of natural immunity of $10 \%$. All parameters and initial conditions except initial fractions of naturally immune individuals are as shown in Table 1. Results shown are median values over 30 trials.

relative fraction of the population that is protected against each viral variant does impact

480 performance of the different vaccinations strategies differently. In particular, when more of the

481 population is already immune to viral variant 1 , it accentuates the benefit of vaccinating against

482 viral variant 2 and vice versa. This is because, when $\sim 10 \%$ of the population has natural

483 immunity to viral variant $1(2)$, vaccinating against this variant means that $\sim 10 \%$ of vaccines are

484 'wasted'. With decreasing levels of natural immunity against viral variant 1(2), however, the 
medRxiv preprint doi: https://doi.org/10.1101/2021.01.05.21249255; this version posted January 6, 2021. The copyright holder for this preprint (which was not certified by peer review) is the author/funder, who has granted medRxiv a license to display the preprint in perpetuity.

It is made available under a CC-BY-NC-ND 4.0 International license .

number of wasted variant 1(2) vaccines decreases. Interestingly, despite the loss of 'wasted' vaccines, vaccinating against the faster spreading second variant is still the better option for

487 preventing deaths, and remains comparable for lowering peak infection rates even when all

488 existing natural immunity is targeted against this strain. This shows how viral transmissibility

489 swamps most other considerations when determining the optimal vaccine target. Notably,

490 however, for all scenarios shown in Figure 5, vaccination against the second variant and the

491 mixed vaccination strategy are comparable, suggesting that a mixed strategy can perform as well

492 or almost as well as specifically targeting the fast-spreading strain (but see Figure 2).

493

494 Discussion

In this paper, I use a stochastic simulation to examine how the choice of vaccine target

496 impacts outcomes of an outbreak of COVID-19 consisting of two different viral variants and for

497 which vaccine cross-protection is incomplete (though not necessarily zero). Although inspired by

498 the recent emergence of the B.1.1.7 COVID-19 strain in the United Kingdom, predictions from

499 this model are not restricted to any particular viral variant. Rather, model predictions hold for

500 any virus strain that emerges and that exhibits a higher $R_{0}$ than the dominant circulating strain $-\mathrm{a}$

501 typical trajectory for virus evolution. Indeed, as I write this paper, it is becoming clear that a

502 second more transmissible COVID-19 strain has emerged in South Africa ${ }^{23}$. Like the UK B.1.1.7

503 strain, the South African variant has the N501Y mutation, although it is otherwise quite different.

504 As with increased transmission, viral variants that 'escape' current antibody responses are

505 also anticipated as a common trajectory of viral evolution. Although many scientists are hopeful

506 that existing vaccines will provide strong cross-protection against the B.1.1.7 viral variant from

507 Southern England, the South African variant appears to have even more mutations in the spike 
medRxiv preprint doi: https://doi.org/10.1101/2021.01.05.21249255; this version posted January 6, 2021. The copyright holder for this preprint (which was not certified by peer review) is the author/funder, who has granted medRxiv a license to display the preprint in perpetuity.

It is made available under a CC-BY-NC-ND 4.0 International license .

508 protein. This reduces the likelihood that current vaccines will be able to neutralize $\mathrm{it}^{24}$. And even

509 if current vaccines are largely effective against both the South England and South African viral

510 variants, as more and more of the global population becomes immune to current circulating

511 COVID-19 strains - either through natural infection or via vaccination - the selective pressures

512 favoring escape mutants will increase. Thus, it is almost inevitable that fast-spreading variants

513 that are not well-covered by existing vaccines will emerge during the course of vaccine roll-out

514 across the globe.

515 One benefit of the technologies being used to develop COVID-19 vaccines and, in

516 particular, of the mRNA vaccine approach, is the ease with which different viral variants can be

517 exchanged during vaccine development and production. However, because mRNA vaccine

518 technologies are relatively new, and have not been systematically tested in human populations

519 prior to the COVID-19 pandemic, it is not clear whether multiple different viral targets can be

520 included simultaneously (i.e., multivalent vaccines). Consequently, I sought to address the

521 question of which viral variant to target in the event that a vaccine can only be produced against

522 a single variant (monovalent) but there are multiple variants circulating.

523 Very broadly, my analysis suggests that it is almost always better to develop vaccines

524 that target the faster spreading viral variant. This is true even when the slower spreading variant

525 is 100- to 1000-fold more prevalent at the onset of the vaccination period and even when cross-

526 protection is relatively high. This outcome is a direct result of the nature of exponential growth.

527 In particular, exponential growth rapidly accentuates even slight differences in populations with

528 different exponential growth rates (or different $R_{0}$ values, in the case of diseases). As a

529 consequence, over a matter of days to months, any initial advantage of the more prevalent but

530 slower spreading viral variant is rapidly swamped by the diverging trajectories of the viral 
medRxiv preprint doi: https://doi.org/10.1101/2021.01.05.21249255; this version posted January 6, 2021. The copyright holder for this preprint (which was not certified by peer review) is the author/funder, who has granted medRxiv a license to display the preprint in perpetuity.

It is made available under a CC-BY-NC-ND 4.0 International license .

531 growth curves. Surprisingly, while targeting the slow spreading variant is rarely beneficial, a

532 mixed strategy, where $50 \%$ of the population receives a vaccine against one strain, and $50 \%$

533 receives a vaccine against the other strain, can perform relatively well, at least when the

534 differences in viral transmission rates are not extreme (e.g. the second viral variant is $\leq 50 \%$ more

535 transmissible than the first). That said, for more extreme differences in transmission rates, the

536 mixed strategy rapidly loses traction, and vaccination against the fast-spreading viral variant can

537 save numerous lives, as well as lower peak infection rates, even relative to the mixed strategy.

538 While most realistic scenarios that I consider suggest that it is best to develop vaccines

539 against the faster-spreading viral variant, this is not universally true. Factors that promote the

540 viability of vaccination against the slow-spreading variant include smaller differences in growth

541 rates between the two viral strains (see Figure 2), as well as faster vaccine roll-outs that leave

542 less time for the fast-spreading virus to overcome its initial lower prevalence (see Figure 3). In

543 addition, vaccination against the slow spreading viral variant is better when a larger relative

544 fraction of the population is already immune to the fast spreading viral variant, when a larger

545 relative fraction of the population is infected with the slow spreading viral variant, and when

546 cross-protection is more complete. Thus, it is not inconceivable that there would be locations

547 where vaccination against the slow spreading strain is preferable. Depending on how many

548 people in Southern England have already been infected with B.1.1.7, for example, it may be

549 more prudent to vaccinate against the original strain. Nevertheless, this appears to be the

550 exception, rather than the rule. More generally, it seems that, for a largely susceptible population,

551 and given current low rates of vaccine disbursement and delivery around the globe, it would be

552 prudent if at least some vaccine companies switched their current formulations to target the 
medRxiv preprint doi: https://doi.org/10.1101/2021.01.05.21249255; this version posted January 6, 2021. The copyright holder for this preprint (which was not certified by peer review) is the author/funder, who has granted medRxiv a license to display the preprint in perpetuity.

It is made available under a CC-BY-NC-ND 4.0 International license .

553 newly emerged, highly transmissible COVID-19 variants that have been discovered in England

554 and South Africa.

555 Although I designed my model to capture a range of important effects that could impact

556 the benefits of different vaccination strategies, my model does make a number of simplifying

557 assumptions. First, and foremost, I do not consider the two-dose vaccination schedule that is

558 currently in use for both the Pfizer-BioNTech vaccine and the Moderna vaccine. Rather, my

559 model ignores priming and assumes that a single vaccine dose results in a person acquiring full

560 immunity. This simplifying assumption is most appropriate if the first dose of vaccine either

561 does not provide much immunity, or else provides nearly complete protection. Predictions will

562 be less accurate, however, if the first dose provides partial immunity that is then increased by the

563 second dose. Another simplifying assumption of my model is that the population is well-mixed

564 and without any structure like age-classes or differences in behavior (e.g., ability to

565 telecommute, willingness to wear masks) that might lead to differential interactions among

566 groups or else different exposure rates or susceptibilities to exposures. As well, I do not consider

567 an exposed class or waning immunity. Likewise, I do not consider differences in infectious

568 period or disease outcomes that may be garnered by immunity, either to the infecting strain or to

569 the off-target strain. In reality, though, it is likely that vaccination would, at the very least, lower

570 death rates of an infection, even if it does not fully protect against infection itself. Another

571 assumption that I make is that, other than transmission rates, both viral variants are largely

572 identical. That is, they induce similar death rates, have similar recovery rates, and illicit similar

573 degrees of cross-protection. Finally, I assume a closed population, with no new individuals or

574 infections introduced. Many of these complexities could be added to my model, though most

575 would require additional parameters which are currently unknown. Nevertheless, as more 
medRxiv preprint doi: https://doi.org/10.1101/2021.01.05.21249255; this version posted January 6, 2021. The copyright holder for this preprint (which was not certified by peer review) is the author/funder, who has granted medRxiv a license to display the preprint in perpetuity.

It is made available under a CC-BY-NC-ND 4.0 International license .

576 information becomes available about newly emerging strains, their relative transmissibilities and

577 the degree of cross-protection, including additional model details and complexities will become

578 more feasible.

579 Overall, my model suggests that, except in very rare instances, monovalent COVID-19

580 vaccines should target the fastest-spreading strain of the virus, regardless of how prevalent that

581 strain is at the outset of the vaccination period, and regardless of the degree of cross-protection

582 offered by either vaccines or natural immunity. For scenarios where targeting the slower-

583 spreading strain is equivalent or even marginally better than targeting the faster-spreading strain,

584 total deaths and peak infection rates tend to be low for all vaccination strategies. However, for

585 scenarios where targeting the faster-spreading strain is best, differences in total deaths and peak

586 infections can be substantial. Thus, even from a precautionary principle, the safest bet is to target

587 the variant with the higher transmission rate. The mixed strategy - vaccinating half of the

588 population against each viral variant - performs nearly as well as vaccinating against the fast

589 spreading virus over a surprisingly large range of viral transmission rates. However, when the

590 fast spreading virus is significantly more transmissible than the original strain, even the mixed

591 strategy can result in a sizeable number of additional deaths as compared to vaccination solely

592 against the fast spreading strain. Thus, for example, for the low estimate that the B.1.1.7 strain is

$59350 \%$ more transmissible than its predecessor, the mixed vaccination strategy is nearly as good as

594 vaccination against B.1.1.7 alone. However, for the high estimate that the B.1.1.7 strain is $70 \%$

595 more transmissible, the mixed strategy dramatically underperforms, leading to nearly $70 \%$ more

596 deaths as compared to a strategy where all vaccine efforts are focused on the B.1.1.7 strain.

597

New strains of COVID-19 will continue to emerge that are more transmissible than the

598 current variants, and that escape or partially escape from the current vaccines. Although we 
medRxiv preprint doi: https://doi.org/10.1101/2021.01.05.21249255; this version posted January 6, 2021. The copyright holder for this preprint (which was not certified by peer review) is the author/funder, who has granted medRxiv a license to display the preprint in perpetuity.

It is made available under a CC-BY-NC-ND 4.0 International license.

cannot prevent this from happening, we can make decisions about vaccination strategies that

minimize the negative health outcomes of such events. Naturally, the best long-term solution will

601 be to develop multivalent mRNA vaccines that simultaneously protect against all dominant

602 COVID-19 viral variants in circulation. Until that is possible, however, my study provides 'rule-

603 of-thumb' guidance for public health officials and vaccine companies alike. Specifically, my

604 study suggests that, in most cases, targeting vaccines against the fastest spreading viral variant

605 will at worst perform equally well as other strategies and, at best, save many lives.

606

607 References

6081 Cucinotta, D. \& Vanelli, M. WHO declares COVID-19 a pandemic. Acta Bio Medica:

$609 \quad$ Atenei Parmensis 91, 157 (2020).

6102 Le, T. T., Andreadakis, Z., Kumar, A., Roman, R. G., Tollefsen, S., Saville, M. \& Mayhew, S. The COVID-19 vaccine development landscape. Nat Rev Drug Discov 19,

612

613 305-306 (2020).

614

615

616

617

618

619

620

621

622

623

624

3 Oliver, S. E., Gargano, J. W., Marin, M., Wallace, M., Curran, K. G., Chamberland, M., Committee on Immunization Practices' Interim Recommendation for Use of PfizerBioNTech COVID-19 Vaccine-United States, December 2020. Morbidity and Mortality Weekly Report 69, 1922 (2020).

4 Oliver, S. E. The Advisory Committee on Immunization Practices' Interim Recommendation for Use of Moderna COVID-19 Vaccine-United States, December 2020. MMWR. Morbidity and Mortality Weekly Report 69 (2020). Akpan, N. Why a coronavirus vaccine could take way longer than a year. National $5 \quad$ Akpan, N. Why a coro

6 Mahase, E. Covid-19: Moderna vaccine is nearly 95\% effective, trial involving high risk and elderly people shows. BMJ: British Medical Journal (Online) 371 (2020).

$7 \quad$ Mahase, E. BMJ 2020;371:m4826.

8 Schlake, T., Thess, A., Fotin-Mleczek, M. \& Kallen, K.-J. Developing mRNA-vaccine technologies. RNA biology 9, 1319-1330 (2012).

9 Jackson, L. A., Anderson, E. J., Rouphael, N. G., Roberts, P. C., Makhene, M., Coler, R. N., McCullough, M. P., Chappell, J. D., Denison, M. R. \& Stevens, L. J. An mRNA vaccine against SARS-CoV-2 - preliminary report. New England Journal of Medicine (2020).

634 Pardi, N., Hogan, M. J., Porter, F. W. \& Weissman, D. mRNA vaccines - a new era in vaccinology. Nature reviews Drug discovery 17, 261 (2018).

635

11 Tang, J. W., Tambyah, P. A. \& Hui, D. S. Emergence of a new SARS-CoV-2 variant in the UK. Journal of Infection (2020). 
medRxiv preprint doi: https://doi.org/10.1101/2021.01.05.21249255; this version posted January 6, 2021. The copyright holder for this preprint (which was not certified by peer review) is the author/funder, who has granted medRxiv a license to display the preprint in perpetuity.

It is made available under a CC-BY-NC-ND 4.0 International license .

$63612 \quad$ Kupferschmidt, K. (American Association for the Advancement of Science, 2021).

63713 Santos, J. C. \& Passos, G. A. The high infectivity of SARS-CoV-2 B. 1.1. 7 is associated with increased interaction force between Spike-ACE2 caused by the viral N501Y mutation.

14 Jackson, C. B., Zhang, L., Farzan, M. \& Choe, H. Functional importance of the D614G mutation in the SARS-CoV-2 spike protein. Biochemical and Biophysical Research Communications (2020).

15 Wise, J. (British Medical Journal Publishing Group, 2020).

16 Mahase, E. (British Medical Journal Publishing Group, 2020). Sano, K., Ainai, A., Suzuki, T. \& Hasegawa, H. The road to a more effective influenza vaccine: Up to date studies and future prospects. Vaccine 35, 5388-5395 (2017). comparative pathology 137, S62-S66 (2007).

19 Gillespie, D. T. Exact stochastic simulation of coupled chemical reactions. The journal of physical chemistry 81, 2340-2361 (1977). Provention, C. C. f. D. C. a. Duration of Isolation and Precautions for Adults with COVID-19, <https://www.cdc.gov/coronavirus/2019-ncov/hcp/duration-isolation.html> (2020).

21 Brazeau, N., Verity, R., Jenks, S., Fu, H., Whittaker, C., Winskill, P., Dorigatti, I., Walker, P., Riley, S. \& Schnekenberg, R. P. Report 34: COVID-19 infection fatality ratio: estimates from seroprevalence. (2020).

22 Liu, Y., Gayle, A. A., Wilder-Smith, A. \& Rocklöv, J. The reproductive number of COVID-19 is higher compared to SARS coronavirus. Journal of travel medicine (2020).

23 Tegally, H., Wilkinson, E., Giovanetti, M., Iranzadeh, A., Fonseca, V., Giandhari, J., Doolabh, D., Pillay, S., San, E. J. \& Msomi, N. Emergence and rapid spread of a new severe acute respiratory syndrome-related coronavirus 2 (SARS-CoV-2) lineage with multiple spike mutations in South Africa. medRxiv (2020). 